\title{
COEFFICIENT ESTIMATES FOR SOME FAMILIES OF BI-BAZILEVIČ FUNCTIONS OF THE MA-MINDA TYPE INVOLVING THE HOHLOV OPERATOR
}

\author{
H. M. SRivastava, G. Murugusundaramoorthy and K. Vijaya
}

\begin{abstract}
In this paper, we introduce and investigate a new subclass of the function class $\Sigma$ of biunivalent functions of the Bazilevič type defined in the open unit disk, which are associated with the Hohlov operator and satisfy some subordination conditions. Furthermore, we find estimates on the Taylor-Maclaurin coefficients $\left|a_{2}\right|$ and $\left|a_{3}\right|$ for functions in the new subclass introduced here. Several (known or new) consequences of the results are also pointed out.
\end{abstract}

Mathematics subject classification (2010): Primary 30C45; Secondary 30C50.

Keywords and phrases: Analytic functions, univalent functions, bi-univalent functions, Bazilevič type functions, bi-starlike and bi-convex functions, Hohlov operator, Gaussian hypergeometric function, TaylorMaclaurin coefficients, Dziok-Srivastava operator, general fractional calculus operator, Srivastava-Wright operator, Carlson-Shaffer operator, Ruscheweyh derivative operator, Bernardi-Libera-Livingston operator.

\section{REFERENCES}

[1] F. M. Al-Aboudi, n-Bazilevič functions, Abstr. Appl. Anal. 2012 (2012), Article ID 383592, 1-10.

[2] A. A. Amer And M. DARus, Distortion theorem for certain class of Bazilevič functions, Internat. J. Math. Anal. 6 (2012), 591-597.

[3] D. A. Brannan and J. G. Clunie (Editors), Aspects of Contemporary Complex Analysis, Proceedings of the NATO Advanced Study Institute (University of Durham, Durham; July 1-20, 1979), Academic Press, New York and London, 1980.

[4] D. A. Brannan, J. Clunie And W. E. Kirwan, Coefficient estimates for a class of star-like functions, Canad. J. Math. 22 (1970), 476-485.

[5] D. A. BRAnnan And T. S. TAHA, On some classes of bi-unvalent functions, in Mathematical Analysis and Its Applications (Kuwait; February 18-21, 1985) (S. M. Mazhar, A. Hamoui and N. S. Faour, Editors), pp. 53-60, KFAS Proceedings Series, Vol. 3, Pergamon Press (Elsevier Science Limited), Oxford, 1988; see also Studia Univ. Babeş-Bolyai Math. 31 (2) (1986), 70-77.

[6] M. ÇAĞLAR, H. ORHAN AND N. YAĞMUR, Coefficient bounds for new subclasses of bi-univalent functions, Filomat 27 (2013), 1165-1171.

[7] J. DZIOK AND H. M. SRIVASTAVA, Classes of analytic functions associated with the generalized hypergeometric function, Appl. Math. Comput. 103 (1999), 1-13.

[8] J. DZIOK AND H. M. SRIVASTAVA, Certain subclasses of analytic functions associated with the generalized hypergeometric function, Integral Transforms Spec. Funct. 14 (2003), 7-18.

[9] E. DENIZ, Certain subclasses of bi-univalent functions satisfying subordinate conditions, J. Classical Anal. 2 (1) (2013), 49-60.

[10] P. L. Duren, Univalent Functions, Grundlehren der Mathematischen Wissenschaften, Band 259, Springer-Verlag, New York, Berlin, Heidelberg and Tokyo, 1983.

[11] B. A. Frasin And M. K. Aouf, New subclasses of bi-univalent functions, Appl. Math. Lett. 24 (2011), 1569-1573.

[12] S. P. GoYAl AND P. GosWAMI, Estimate for initial Maclaurin coefficients of bi-univalent functions for a class defined by fractional derivatives, J. Egyptian Math. Soc. 20 (2012), 179-182. 
[13] T. Hayami And S. Owa, Coefficient bounds for bi-univalent functions, Pan Amer. Math. J. 22 (4) (2012), 15-26.

[14] YU. E. Hohlov, Convolution operators that preserve univalent functions, Ukrain. Mat. Zh. 37 (1985), 220-226.

[15] Yu. E. HoHLOv, Hadamard convolutions, hypergeometric functions and linear operators in the class of univalent functions, Dokl. Akad. Nauk Ukrain. SSR Ser. A 1984 (7) (1984), 25-27.

[16] Y. C. Kim AND H. M. SRIVASTAVA, The Hardy space of a certain subclass of Bazilevič functions, Appl. Math. Comput. 183 (2006), 1201-1207.

[17] Y. C. Kim And T. Sugawa, A note on Bazilevič functions, Taiwanese J. Math. 13 (2009), 1489-1495.

[18] V. Kiryakova, Generalized Fractional Calculus and Applications, Pitman Research Notes in Mathematics, Vol. 301, Longman Scientific and Technical, Harlow (Essex), 1993.

[19] V. Kiryakova, Criteria for univalence of the Dziok-Srivastava and the Srivastava-Owa operators in the class A, Appl. Math. Comput. 218 (2011), 883-892.

[20] M. LEwIN, On a coefficient problem for bi-univalent functions, Proc. Amer. Math. Soc. 18 (1967), 63-68.

[21] X.-F. Li And A.-P. WANG, Two new subclasses of bi-univalent functions, Internat. Math. Forum 7 (2012), 1495-1504.

[22] W. C. MA AND D. Minda, A unified treatment of some special classes of functions, in Proceedings of the Conference on Complex Analysis (Tianjin, 1992), pp. 157-169, Conference Proceedings Lecture Notes in Analysis, Vol. 1, International Press, Cambridge, Massachusetts, 1994.

[23] S. S. Miller And P. T. Mocanu, Differential Subordination: Theory and Applications, Series on Monographs and Textbooks in Pure and Applied Mathematics, No. 225, Marcel Dekker Incorporated, New York and Basel, 2000.

[24] E. NetANYAhu, The minimal distance of the image boundary from the origin and the second coeffcient of a univalent function in $z<1$, Arch. Rational Mech. Anal. 32 (1969), 100-112.

[25] K. I. Noor AND K. AhmAD, On higher order Bazilevič functions, Internat. J. Modern Phys. B 27 (4) (2013), Article ID 1250203, 1-14.

[26] T. Panigarhi and G. Murugusundaramoorthy, Coefficient bounds for bi-univalent functions analytic functions associated with Hohlov operator, Proc. Jangjeon Math. Soc. 16 (2013), 91-100.

[27] C. Pommerenke, Univalent Functions, Vandenhoeck and Ruprecht, Göttingen, 1975.

[28] W. Rogosinski, On the coefficients of subordinate functions, Proc. London Math. Soc. (Ser. 2) 48 (1943), 48-82.

[29] C. Selvaraj And C. S. Moni, Subordination results for a class of Bazilevič functions with respect to symmetric points, Stud. Univ. Babeş-Bolyai Math. 58 (1) (2013), 23-30.

[30] R. Singh, On Bazilevič functions, Proc. Amer. Math. Soc. 28 (1973), 261-271.

[31] H. M. SRIVASTAVA, Some Fox-Wright generalized hypergeometric functions and associated families of convolution operators, Appl. Anal. Discrete Math. 1 (2007), 56-71.

[32] H. M. SRIVAstava, S. Bulut, M. ÇAĞLAR AND N. YAĞMUR, Coefficient estimates for a general subclass of analytic and bi-univalent functions, Filomat 27 (2013), 831-842.

[33] H. M. Srivastava, A. K. Mishra and P. Gochhayat, Certain subclasses of analytic and biunivalent functions, Appl. Math. Lett. 23 (2010), 1188-1192.

[34] H. M. Srivastava, G. Murugusundaramoorthy and N. Magesh, Certain subclasses of biunivalent functions associated with the Hohlov operator, Global J. Math. Anal. 1 (2) (2013), 67-73.

[35] H. M. SRIVastava And S. Owa (Editors), Current Topics in Analytic Function Theory, World Scientific Publishing Company, Singapore, New Jersey, London and Hong Kong, 1992.

[36] T. S. TAHA, Topics in Univalent Function Theory, Ph. D. Thesis, University of London, 1981.

[37] Q.-H. XU, Y.-C. Gui AND H. M. SRIVASTAVA, Coefficient estimates for a certain subclass of analytic and bi-univalent functions, Appl. Math. Lett. 25 (2012), 990-994.

[38] Q.-H. XU, H.-G. XIAO AND H. M. SRIVASTAVA, A certain general subclass of analytic and biunivalent functions and associated coefficient estimate problems, Appl. Math. Comput. 218 (2012), $11461-11465$.

[39] Z.-G. WANG AND H.-T. WANG, A class of multivalent non-Bazilevic functions fnvolving the ChoKwon-Srivastava operator, Tamsui Oxford J. Math. Sci. 26 (2010), 1-19. 